\title{
Biomass Utilization as Renewable Energy for Optimization of National Energy Mix
}

\author{
Arif Haryana ${ }^{1}$ \\ Ministry of National Development Planning/BAPPENAS RI
}

\begin{abstract}
Indonesia still relies heavily on energy derived from fossil fuels, especially petroleum and coal. The large share of fossil energy in the national energy mix can have a negative impact on national development, as it increases the dependence of national energy supplies from imports and increases in greenhouse gas emissions, carbon dioxide. The Government of Indonesia has issued a national energy policy whose goal is to achieve an optimal national energy mix, which is to reduce the share of fossil fuels and increase the use of renewable energy. Indonesia has the potential to produce abundant biomass as renewable energy and can use it to replace fossil fuels. However, the development and utilization of biomass as an energy source is still very small compared to its potential. Biomass energy development policy has begun to receive attention from the government, although it is still focused on the development and use of liquid biofuels, especially palm oil-based biodiesel. There is no clear policy to support the development and utilization of solid biomass to meet national energy needs. Meanwhile, foreign countries, Korea for example, have developed a strategy to utilize Indonesia's biomass as fuel for their power plants. As a country with huge biomass potential, it is ironic that Indonesia has not used biomass as a source of energy to support development, while other countries use it. This paper aims to provide policy recommendations for developing biomass energy, both in terms of production capacity and demand for use in the country.
\end{abstract}

Keywords: biomass, renewable energy, energy mix policy 
Pengembangan Pemanfaatan Biomassa sebagai Energi Terbarukan untuk Mencapai Bauran Energi Nasional yang Optimal

\section{Arif Haryana, BAPPENAS}

\section{Pendahuluan}

Pertumbuhan ekonomi yang pesat dapat dicapai dengan meningkatkan produktivitas melalui investasi dan ketersediaan energi yang cukup untuk mendorong pertumbuhan. Keadaan ini menyebabkan meningkatnya permintaan akan energi. Sementara energi sangat penting untuk mendorong pembangunan, pada saat bersamaan Indonesia juga membutuhkan dana untuk membiayai investasi pembangunan, yang juga diperoleh dari ekspor komoditas energi. Hingga saat ini, pertumbuhan dan perkembangan Indonesia telah dihasilkan dari investasi pembangunan yang didukung terutama oleh energi berbasis fosil seperti minyak bumi dan batu bara.

Saat ini Indonesia mengalami kesenjangan antara produksi dan permintaan energi minyak bumi. Kebutuhan dan permintaan energi terus meningkat untuk mendukung pembangunan dan pertumbuhan ekonomi. Sementara itu, dalam waktu yang sama kapasitas dalam produksi minyak Indonesia cenderung turun. Kesenjangan antara permintaan dan produksi tersebut cenderung semakin melebar. Thacker (2014) memperkirakan bahwa Indonesia pada tahun 2025 mungkin harus mengimpor lebih dari 70 persen kebutuhan minyak nasionalnya karena berkurangnya produksi minyak di dalam negeri dan meningkatnya permintaan energi. Oleh karena itu, perlu adanya upaya serius untuk mencari sumber energi alternatif pengganti bahan bakar fosil, di samping upaya konservasi energi dengan meningkatkan efisiensi penggunaan energi. Bioenergi atau energi biomassa merupakan salah satu jenis energi terbarukan yang dapat menunjang pertumbuhan ekonomi yang sejalan dengan tujuan pembangunan berkelanjutan.

Bioenergi memiliki peran dan makna strategis bagi Indonesia. Negara Republik Indonesia mencakup wilayah yang sangat luas dan terdiri atas beberapa pulau besar dan ribuan pulaupulau kecil yang tersebar. Kondisi ini mempersulit transmisi dan distribusi listrik maupun BBM. Interkoneksi jaringan listrik yang efisien secara ekonomi hanya mungkin untuk pulau-pulau besar dan sejumlah pulau-pulau relatif kecil di dekatnya. Oleh karena itu, sejumlah besar pulau harus bisa menghasilkan dan memenuhi kebutuhan bahan bakar dan listriknya sendiri (selfsufficient). Namun demikian, banyak wilayah dan pulau tidak memiliki cadangan bahan bakar fosil yang memadai. Kondisi ini menjadikan biomassa memiliki peran dan makna yang strategis dalam penyediaan energi, karena sumber daya hayati biomassa tersedia di semua pulau.

Dengan posisi geografis wilayah tropis yang terbentang luas di sepanjang garis khatulistiwa, Indonesia memiliki salah satu peluang terbaik di dunia untuk menghasilkan biomassa yang melimpah. Sumber energi terbarukan ini belum berkembang, namun memiliki prospek bagus untuk menjadi sumber energi penting untuk mendorong pertumbuhan ekonomi Indonesia.

Pellet kayu, salah satu produk pembawa energi biomassa memiliki keunggulan dibandingkan dengan bahan bakar fosil, antara lain dapat diperbarui (renewable), efisien karena biaya lebih rendah, bersih, lebih ekonomis, mudah penggunaannya baik untuk penghasil energi termal untuk keperluan rumah tangga (misalnya memasak) maupun untuk pembangkit listrik dan ramah lingkungan karena kadar karbon yang dihasilkan lebih rendah.

Negara lain mengincar potensi energi biomassa Indonesia dan sudah mengembangkan strategi untuk memanfaatkannya sebagai bahan bakar untuk pembangkit tenaga listrik. Sebagai contoh, investor Korea Selatan telah bekerjasama dengan PT Inhutani III untuk membangun industri pengolahan pellet kayu untuk diekspor ke Korea. Sebagai negara dengan potensi biomassa yang sangat besar, ironis jika biomassa belum banyak dimanfaatkan sebagai sumber energi pembangkit listrik, sementara justru negara lain yang memanfaatkannya.

Kebijakan bidang energi dalam pembangunan nasional mencakup aspek-aspek yang sangat luas dan kompleks. Policy paper ini tidak berpretensi untuk membahas semua aspek tersebut, namun dibatasi ruang lingkupnya pada kebijakan untuk mengembangkan biomassa yang sangat besar potensinya menjadi sumber energi yang dapat dimanfaatkan oleh masyarakat luas. Paper ini bertujuan untuk mengidentifikasi dan menganalisis permasalahan bioenergi yang ada 
dan memberikan rekomendasi kebijakan yang optimal untuk mengembangkan pemanfaatan biomassa sebagai sumber energi terbarukan, baik dalam sisi produksi maupun pengembangan permintaan untuk penggunaan dalam negeri.

Analisis dan review kebijakan pengembangan biomassa sebagai sumber energi dilakukan berdasarkan analisis pada dua sisi pasar utama, yaitu sisi permintaan dan sisi pasokan/suplai. Pada sisi permintaan, review didasarkan pada proyeksi permintaan sesuai arah kebijakan menuju bauran energi nasional yang optimum sebagaimana dituangkan dalam Rencana Umum Energi Nasional (RUEN). Permintaan ini kemudian dibandingkan dengan ketersediaan pasokan dan potensi penyediaan pasokan sesuai dengan ketersediaan sumberdaya yang ada. Analisis kebijakan pengembangan biomassa sebagai sumber energi didasarkan pada kesenjangan antara potensi ketersediaan dan pemanfaatan sumberdaya biomassa sebagai sumber energi.

Analisis atau review kebijakan tersebut diarahkan untuk melihat aspek: (a) pengembangan produksi dan keberlanjutan pasokan, (b) pengembangan pemanfaatan dan permintaan dalam negeri, (c) sistem kelembagaan, termasuk tata kelola industri dan pengaturan pasar.

\section{Kebijakan Energi Nasional Menuju Bauran Energi Optimal}

Visi kebijakan energi adalah menjamin pasokan energi yang berkelanjutan untuk mendukung pembangunan nasional. Menghadapi guncangan minyak global di awal tahun 1980an, Indonesia meluncurkan Inpres Nomor 9 Tahun 1982 sebagai prakarsa kebijakan untuk mengatasi tantangan terkait pasokan energi yang ada saat ini. Kebijakan energi nasional terutama difokuskan pada konservasi energi. Ruang lingkup kebijakan difokuskan untuk mengarahkan semua kementerian dan badan pemerintah dan badan usaha milik negara untuk melakukan tindakan konservasi energi.

Kebijakan konservasi energi terus berlanjut selama tahun 1990an, namun aspek lingkungannya memasuki proses perumusan kebijakan. Kebijakan tersebut ditetapkan melalui Keputusan Presiden No. 43/1991 tentang Konservasi Energi. Konservasi energi diterapkan pada semua penggunaan energi. Kebijakan tersebut memberi perhatian lebih besar pada efisiensi energi dan kelestarian lingkungan. Sumber energi terbarukan seperti biomassa sudah mulai mendapat perhatian lebih pada kebijakan energi.

Setelah tahun 2000an, kebijakan energi di Indonesia berfokus pada sisi penawaran dan permintaan dengan empat tujuan kebijakan, yaitu: (i) Diversifikasi energi, (ii) penetapan harga energi secara rasional, (iii) Reformasi sektor energi, dan (iv) listrik pedesaan. Pada sisi penawaran, kebijakan tersebut berfokus pada konservasi energi dan intensifikasi, mengurangi ketergantungan minyak, meningkatkan pasokan energi dari sumber daya tak terbarukan (batubara dan gas) dan sumber terbarukan, elektrifikasi daerah pedesaan. Kebijakan sisi permintaan adalah pada mekanisme penetapan harga yang lebih baik, dan lebih terfokus pada pengurangan subsidi, merangsang daya saing di antara sumber energi yang berbeda berdasarkan prinsip diversifikasi dan efisiensi energi. (Singh dan Setiawan, 2013)

Posisi energi baru dan terbarukan (EBT), termasuk biomassa, sebagai sumber energi alternatif menjadi lebih jelas dengan adanya Kebijakan Energi Nasional (KEN) yang tertuang dalam Peraturan Pemerintah No. 79/2014. Peraturan ini memberikan paradigma baru bahwa sumber energi merupakan modal pembangunan nasional, dan memberikan dasar hukum dan arah bagi pengembangan energi terbarukan di Indonesia dengan adanya sasaran nasional menuju campuran energi yang optimal pada tahun 2050 (Gambar 1).

Gambar 1. Sasaran Bauran Energi Nasional 2025 dan 2050

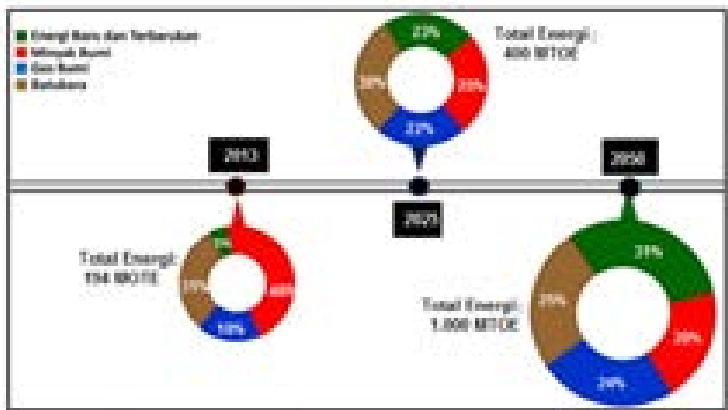


RUEN sudah memberikan arah bauran energi nasional pada 2025, bahkan 2050, namun sampai saat ini belum ada kebijakan yang jelas dalam mendukung pengembangan dan pemanfaatan biomassa padat untuk memenuhi kebutuhan energi nasional. Meskipun demikian, sudah ada beberapa inisiatif untuk mengembangkan produksi energi biomassa padat dalam bentuk pellet kayu karena adanya permintaan untuk pasar ekspor. Jika hal ini tidak ditangani dengan baik, ada kemungkinan pengembangannya akan menjadikan biomassa sebagai komoditas dagang saja, yang berperan sekedar untuk memperoleh devisa; perannya sebagai sumber energi penggerak roda perekonomian yang memberikan efek pengganda dalam pembangunan nasional menjadi terbatas. Lebih dari itu, ekspor biomassa dalam jangka panjang akan berakibat buruk, lahan pertanian/hutan menjadi kurus/tandus karena mineral lahan yang terserap dalam biomassa terangkut keluar dari ekosistem secara masif seiring dengan volume niaga sektor energi yang masif. Jika biomassa dimanfaatkan secara lokal, maka mineral sisa pembakaran dapat dikembalikan ke lahan untuk mempertahankan kesuburannya.

Dukungan kebijakan yang diberikan untuk pengembangan bioenergi masih terfokus pada biomassa cair. Padahal hampir separuh penduduk Indonesia masih menggunakan biomassa padat berupa kayu bakar. Namun, hingga saat ini, belum ada kebijakan dan program mengatasi masalah dalam penggunaan bahan bakar biomassa untuk memasak di rumah tangga, terutama terkait dengan masalah kesehatan akibat penggunaan kayu bakar. Menurut data WHO 2012, secara global terdapat 4,3 juta jiwa meninggal prematur oleh penyakit akibat polusi udara yang disebabkan penggunaan bahan bakar padat. Sedangkan di Indonesia, diprediksi terjadi 45.000 kematian prematur pada wanita dan anak-anak akibat polusi tersebut (YLKI, 29 Maret 2017).

\section{Permasalahan Dalam Pengembangan Energi Biomassa}

Permasalahan yang akan dihadapi dalam pengembangan biomassa sebagai sumber energi dapat dilihat dari prospek dan dinamika antara sisi permintaan pasar dan sisi penyediaannya. Di samping itu, permasalahan dalam faktor kelembagaan yang mempengaruhi kedua sisi pasar tersebut juga berpengaruh terhadap pengembangan energi biomassa.

\subsection{Masalah Terkait Ketersediaan dan Pasokan Energi Biomassa}

Mengingat letak geografisnya dan ukurannya yang besar, Indonesia memiliki salah satu peluang terbaik di dunia untuk memproduksi dan memasok biomassa. Prastowo (2012) menghitung potensi energi bersumber residu biomassa padat dengan menggunakan data tanaman tahun 2010 dan menemukan bahwa Indonesia dapat menghasilkan energi sekitar 756,1 juta GJ per tahun, dimana sekitar 614,6 juta GJ/tahun dari residu pertanian dan 141,5 juta GJ/tahun dari limbah hutan. ZREU (2010) membuat perhitungan mengenai potensi produksi energi biomassa untuk tahun 2007 dan 2010. Perhitungan tersebut menghasilkan potensi sekitar 470 juta GJ/tahun pada tahun 2010, lebih tinggi dari tahun 2007 yang sekitar 441 juta GJ/tahun. Hasil perhitungan oleh ZREU maupun Prastowo juga menunjukkan bahwa selama sekitar satu dekade potensi produksi energi biomassa telah meningkat.

Meski potensi energi dari biomassa sangat besar dan semakin meningkat, namun pemanfaatannya masih sangat terbatas. Pada 2015 porsi EBT dalam bauran energi nasional hanya sebesar 5 persen. Dewan Energi nasional juga menunjukkan betapa kecilnya pemanfaatan energi biomassa untuk pembangkitan tenaga listrik. Dari potensi sebesar $32.654 \mathrm{MW}$, kapasitas terpasangnya baru $1.716 \mathrm{MW}$ atau hanya 5 persen (Tabel 1).

Tabel 1. Potensi dan Kapasitas Terpasang Pembangkit Listrik EBT

\begin{tabular}{|c|c|c|}
\hline Sumber Enerdi Terbarukan & $\begin{array}{l}\text { Potensi } \\
\text { OMWW }\end{array}$ & $\begin{array}{c}\text { Kapasitas } \\
\text { Terpinane } \\
\text { (MW }\end{array}$ \\
\hline 1.Hpdro & 75,000 & 757200 \\
\hline 2 Ceotherma & 23910 & 134350 \\
\hline 1 Minimincro-firdro & 10013 & 8000 \\
\hline 4. Biomass? & 32.654 & 171650 \\
\hline 5. Solar (0.WW/m2/Tag) & 4,8 & 4277 \\
\hline 6. Wind $[3-6 \mathrm{mw}]$ & 9.20 & 1.87 \\
\hline 7. Ocean energy & 49 & 0.01 \\
\hline
\end{tabular}

*) 1.626 MW off grid dan 90,5 MW on grid (Status Desember 2013) Sumber: Dewan Energi Nasional (2015) 
Masalah utama dalam pengembangan dan pemanfaatan biomassa karena sampai saat ini belum ada arah kebijakan dan peta jalan yang jelas. Beberapa negara, termasuk Malaysia, sudah memiliki peta jalan pengembangan industri biomassa, yang arahnya bahkan lebih jauh dari bahan baku untuk energi tetapi sampai pada industri kimia yang memiliki nilai tambah tinggi.

Namun demikian, dukungan kebijakan yang jelas suah diberikan pada pengembangan biomassa cair (Bahan Bakar Nabati/BBN), yaitu berupa:

- Diterbitkannya Inpres No. 1/2006 untuk pengembangan BBN dan dibuatnya Peta Jalan pengembangan dan pemanfaatan biofuel, khususnya biodiesel dan bioetanol.

- Kepastian pasar dengan adanya aturan kewajiban minimal pemanfaatan biodiesel sebagai campuran BBM hingga 2020 dan 2025 (Permen ESDM No 32 Tahun 2008, yang telah dua kali disesuaikan melalui Permen ESDM No 25 tahun 2013 dan Permen ESDM No 20 tahun 2014).

- Adanya jaminan kepastian pengusahaan kepada produsen, kebijakan pengaturan bahan baku termasuk penyiapan alokasi lahan khusus (dedicated land) untuk BBN, dan kebijakan fiskal diantaranya pembebasan pajak.

- Dukungan pembiayaan yang jelas. Selain adanya subsidi, sudah ada dukungan pembiayaan yang berasal dari dana pungutan usaha kelapa sawit. Kebijakan ini tertuang dalam Permen ESDM No. 29 Tahun 2015.

Selain belum adanya dukungan kebijakan yang jelas, masalah yang akan dihadapi adalah adanya kompetisi, baik dalam alokasi lahan maupun penggunaan produk biomassa untuk keperluan energi, bahan pangan, dan pakan ternak. Dengan demikian perlu kebijakan yang optimal untuk mengatasi masalah-masalah tersebut.

\subsection{Permasalahan dalam mendorong penggunaan di dalam negeri}

Peraturan Pemerintah Nomor 79 Tahun 2014 tentang Kebijakan Energi Nasional (KEN) mengamanatkan peningkatan kontribusi EBT dalam bauran pasokan energi nasional yang lebih cepat dibanding sasaran dalam Inpres 6/2006. Berdasarkan KEN tersebut telah dibuat Rencana Umum Energi Nasional (RUEN) yang dituangkan dalam Peraturan Presiden No 22 tahun 2017. Sesuai KEN/RUEN, kontribusi EBT dalam bauran energi nasional direncanakan lebih dari 23 persen pada 2025, dan lebih dari 31 persen pada 2050.

Kebijakan tersebut mengindikasikan bahwa pemerintah akan mendorong penggunaan EBT, termasuk biomassa di dalam negeri, sehingga permintaan energi biomassa akan meningkat cukup cepat. Kenyataan bahwa saat ini pangsa biomassa dalam bauran energi nasional masih sangat rendah menggambarkan besarnya tantangan yang akan dihadapi. Peluang peningkatan penggunaan biomassa terutama pada sektor rumah tangga dan Usaha Mikro Kecil dan Menengah (UMKM), sektor industri, dan sektor pembangkit tenaga listrik. Masing-masing sektor pengguna tersebut menghadapi masalahnya masing-masing. Berikut ini diuraikan beberapa masalah yang dihadapi untuk meningkatkan penggunaan energi biomassa di dalam negeri.

\subsubsection{Masalah dalam Penggunaan Biomassa pada Rumah Tangga dan UMKM}

Pilihan penggunaan bahan bakar pada rumah tangga juga dipengaruhi oleh harga relatif antar bahan bakar, ketersediaan dan kemudahan untuk mengaksesnya. Penggunaan energi biomassa padat dalam rumah tangga masih besar. Hampir separuh dari jumlah rumah tangga masih menggunakan kayu bakar untuk keperluan memasak, dan sebagian besar berada di pedesaan, meskipun program konversi penggunaan bahan bakar dari minyak tanah ke gas telah dilaksanakan dan dinilai berhasil. Jika wacana untuk mencabut subsidi gas elpiji $3 \mathrm{~kg}$ diimplementasikan, maka harga gas elpiji $3 \mathrm{~kg}$ akan menjadi mahal dan masyarakat miskin akan bermigrasi ke kayu bakar lagi.

Dalam kaitannya dengan penggunaan bahan bakar pada rumah tangga, hal penting yang juga harus diperhatikan adalah efisiensi pembakaran dan masalah kesehatan masyarakat pengguna. Pada umumnya penggunaan kayu bakar untuk kegiatan memasak masyarakat perdesaan masih menggunakan tungku tradisional yang efisiensi pembakarannya sangat rendah dan proses pembakarannya tidak sempurna. Kalor atau panas yang dihasilkan dari pembakaran sebagian besar terbuang, dan hanya sekitar 10 persen yang efektif untuk memasak. ${ }^{1}$ Efisiensi yang rendah ini berdampak pada tingkat konsumsi bahan bakar kayu yang tinggi.

Dampak lain dari pembakaran yang tidak sempurna adalah banyaknya asap sisa

1. Arif Budianto, M. Nurhuda, Ahmad Nadhir. Uji Efisiensi Tungku Tanah Liat Berdaya Sedang. Jurusan Fisika FMIPA Universitas Brawijaya, Malang. 
pembakaran yang mengandung zat-zat berbahaya seperti partikel debu, karbon monoksida (CO) dan nitrogen oksida (NOx). Asap yang timbul dari penggunaan kayu bakar dalam aktivitas masak-memasak menjadi kontributor utama penyebab terancamnya kesehatan masyarakat, terutama perempuan. Oleh karena itu dalam pengembangan penggunaan biomassa padat pada sektor rumah tangga perlu dilengkapi pula dengan kebijakan dan program untuk meningkatkan efisiensi bakar dan menjamin agar kesehatan masyarakat terjaga.

\subsubsection{Masalah dalam Penggunaan Biomassa pada Sektor Industri dan Pembangkit Tenaga Listrik}

Faktor penting yang mempengaruhi pilihan penggunaan bahan bakar pada bidang industri dan pembangkit tenaga listrik di dalam negeri adalah kepastian ketersediaan pasokan yang berkelanjutan, harga, dan kompetisi dalam akses untuk memperoleh biomassa.

Dalam institusi bisnis, pertimbangan penting dalam pilihan penggunaan bahan baku, termasuk bahan bakar adalah biaya atau harga yang lebih murah. Oleh karena itu, sektor industri atau pembangkit tenaga listrik akan menggunakan energi biomassa jika harganya kompetitif dibanding jenis bahan bakar lain. Harga bahan bakar minyak, gas dan batu bara yang lebih murah merupakan masalah yang menjadi kendala penting dalam upaya mendorong penggunaan biomassa pada bidang industri dan pembangkit listrik.

Selain masalah harga feedstock, penggunaan bahan biomassa juga sangat terkait dengan persaingan untuk mendapatkannya. Dalam hal ini industri atau pembangkit listrik dalam negeri akan berkompetisi dengan para eksportir untuk mendapatkan energi biomassa karena meningkatnya permintaan pasar dunia. Meningkatnya permintaan pasar ekspor akan mendorong bertumbuhnya industri pengolahan energi biomassa padat berupa pellet.

Masalah kompetisi permintaan pasar dunia tampaknya akan sangat kuat. Hal ini didukung dengan meningkatnya permintaan dunia akan pellet biomassa, baik untuk kebutuhan energi maupun industri biokimia. Stelte (2012) memperkirakan total konsumsi pellet untuk bahan baku energi dan industri biokimia di pasar dunia meningkat hampir empat kali lipat, dari sekitar 16 juta ton pada tahun 2010 menjadi 59 juta ton pada tahun 2020. Kersh dan Soare (2013) juga memperkirakan permintaan biomassa akan meningkat tiga kali lipat pada tahun 2030. Hal ini akan mendorong perdagangan bahan baku di pasar internasional, namun dapat menekan penyediaan bahan baku untuk kebutuhan domestik.

Kawasan Eropa merupakan pasar dan konsumen pellet kayu utama dunia. Kawasan Asia Timur, khususnya Korea Selatan, Jepang dan Cina juga mulai bergerak menjadi pasar biomassa yang signifikan. Permintaan biomassa di kedua kawasan tersebut menjadi penentu peningkatan permintaan biomassa yang signifikan. Kajian yang dilakukan Hoefnagels, et.al. (2013) menyampaikan fakta bahwa permintaan peragangan pellet kayu akan tumbuh maksimal 70 juta ton pada tahun 2030, yang juga berarti bahwa pasokan pellet untuk Eropa akan semakin bergantung pada impor. Meningkatnya permintaan biomassa Eropa merupakan hasil dari langkah Uni Eropa (EU) bergerak menuju peningkatan upaya untuk mengurangi emisi karbon dengan mengadopsi Directive 2009/28/EC tentang Renewable Energy secara resmi.

Permintaan energi biomassa pelet kayu di Jepang, Korea Selatan dan Cina, adalah untuk pemanasan ruang dan penggunaan industri, terutama co-firing dengan batubara untuk pembangkit listrik. Penggunaan biomassa untuk pembangkit listrik di Korea Selatan didorong dengan diterapkannya kebijakan Renewable Portfolio Standard (RPS).

Evans (2013) melaporkan bahwa Kebijakan RPS menetapkan kuota yang mewajibkan pembangkit listrik meningkatkan proporsi listrik bersumber EBT dari 2 persen hingga mencapai 10 persen pada 2022. Konsekuensi kebijakan ini adalah bahwa Korea akan mengimpor 75-80 persen pellet biomassa yang dikonsumsinya. Salah satu upaya yang dilakukan adalah melakukan kerjasama dengan perusahaan di Indonesia untuk mengembangkan biomassa di beberapa daerah. Hal ini akan menjadi kompetitor yang dapat menekan ketersediaan pasokan biomassa untuk penggunaan dalam negeri.

\section{Analisis Kebijakan dalam Pengembangan Energi Biomassa}

Tiga tantangan utama yang dihadapi dalam pengembangan dan pemanfaatan energi biomassa, yaitu: (i) pengembangan produksi energi biomassa untuk memenuhi permintaan pasar, (ii) perluasan pemanfaatan dan permintaan energi biomassa di dalam negeri, dan (iii) pengembangan sistem kelembagaan dan pengaturan pasar. Hal ini memerlukan kebijakan yang tepat sehingga pengembangan energi biomassa dapat memberikan manfaat yang optimal bagi pembangunan nasional, sekaligus mendorong pencapaian bauran energi yang optimal pada 2025 dan 2050. Analisis mengenai hal ini dapat dilihat pada Tabel 2. 


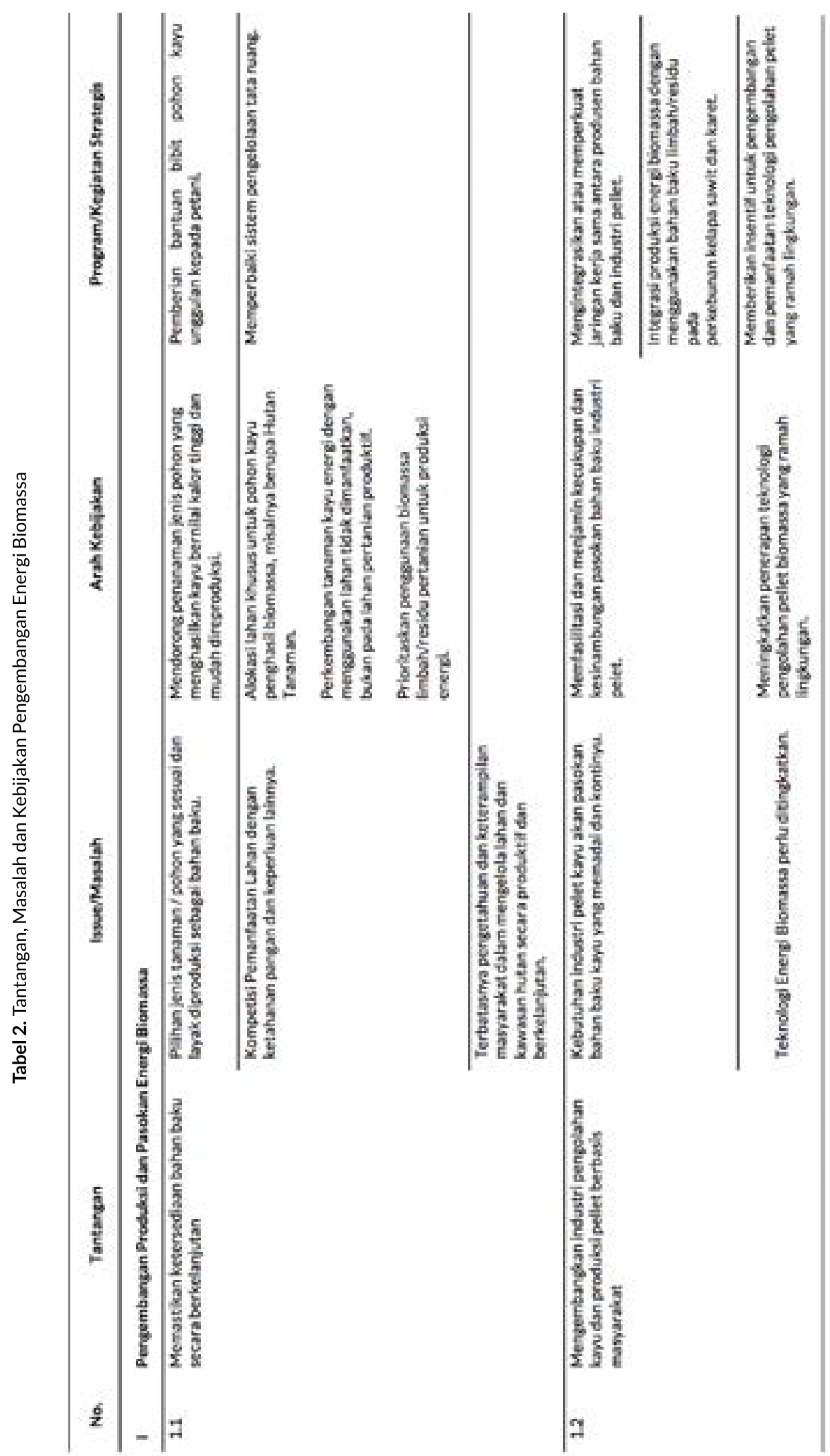




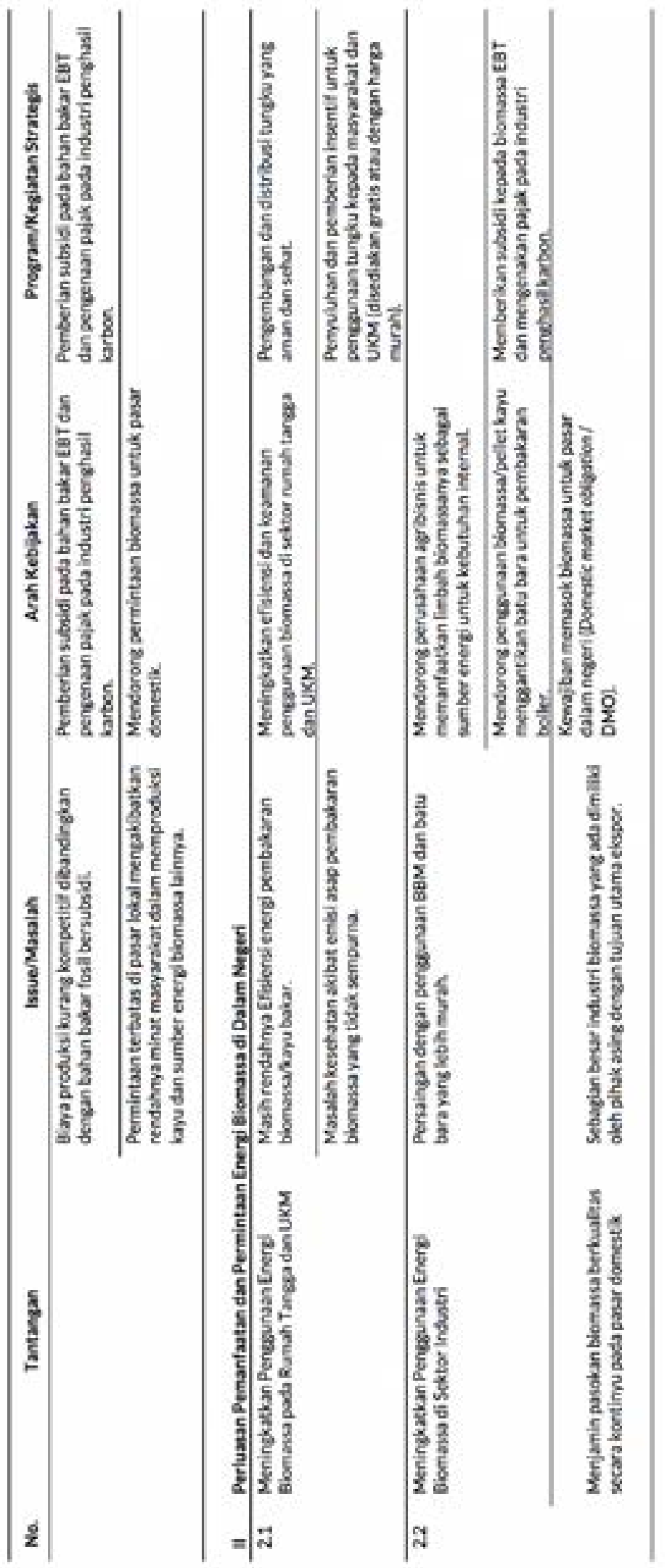




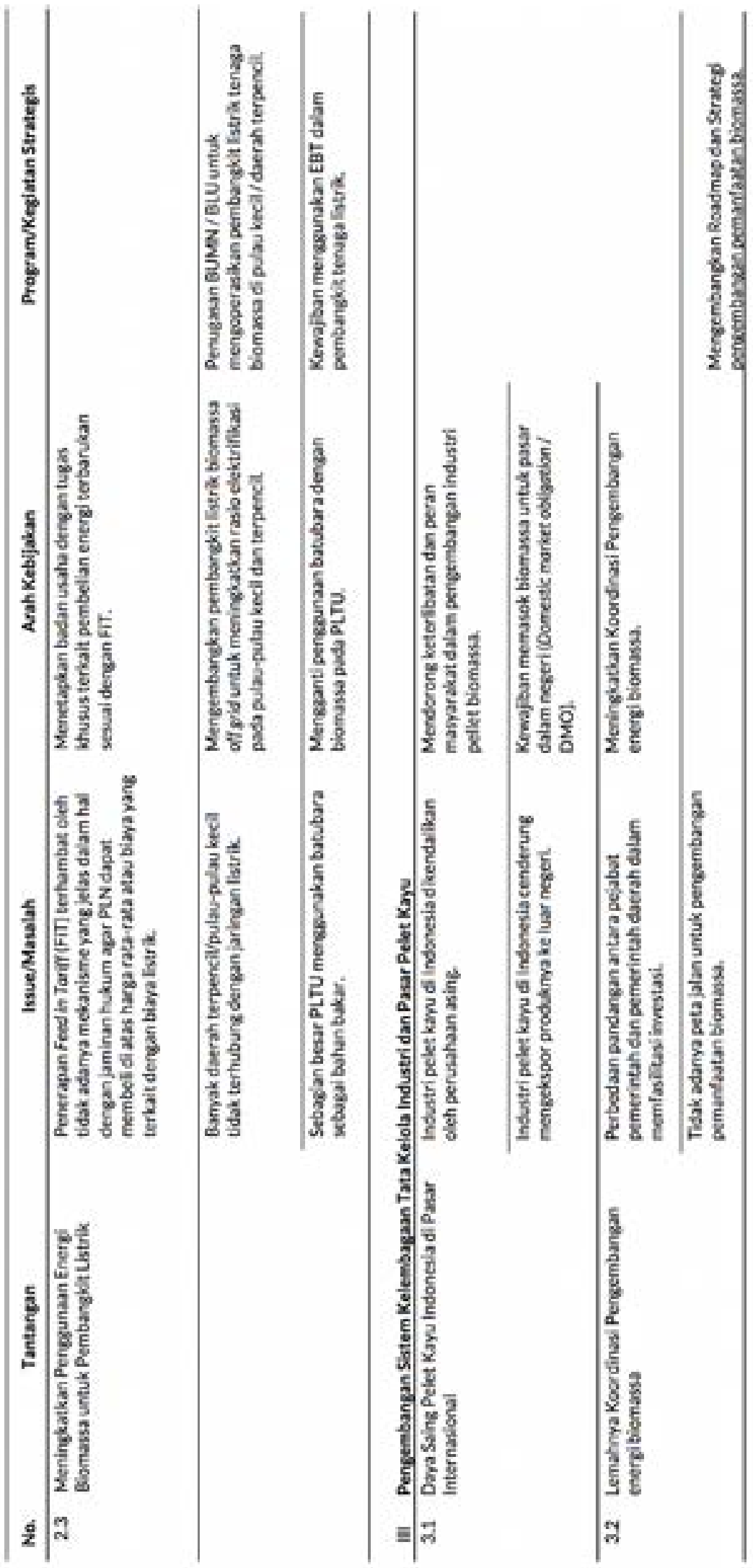




\section{Kesimpulan dan Rekomendasi Kebijakan}

\subsection{Kesimpulan}

Pengembangan biomassa sebagai sumber energi merupakan pilihan hal yang sangat penting dalam rengka memenuhi kebutuhan energi yang semakin meningkat, serta untuk mencapai bauran energi nasional yang optimal sebagaimana yang diarahkan dalam Kebijakan Energi Nasional (KEN).

Pengembangan energi biomassa diutamakan untuk memenuhi kebutuhan energi dalam negeri, meskipun masih dimungkinkan untuk ekspor. Beberapa tantangan yang dihadapi dalam pengembangan energi biomassa adalah:

1. Jaminan ketersediaan feedstock secara efisien dan berkelanjutan.

2. Kompetisi penggunaan biomassa dan penggunaan lahan untuk keperluan ketahanan penyediaan pangan.

3. Perluasan penggunaan dan permintaan energi biomassa di dalam negeri: pada sektor rumah tangga dan UKM, pada sektor industri, dan pada pembangkitan tenaga listrik.

4. Pengembangan sistem kelembagaan dan pengaturan pasar yang menjamin penggunaan biomassa terutama untuk mendukung pembangunan dalam negeri.

\subsection{Rekomendasi Kebijakan}

Terkait dengan tantangan tersebut, direkomendasikan kebijakan dalam tiga kelompok sebagai berikut.

\subsubsection{Pengembangan Produksi dan Pasokan Energi Biomassa:}

a. Mendorong penanaman jenis pohon yang menghasilkan kayu bakar bernilai kalor tinggi dan mudah diperbanyak. Untuk itu Pemerintah perlu memberikan insentif bibit tanaman kayu bakar unggul pada lahan petani melalui kelompok tani. Jenis tanaman yang bisa direkomendasikan antara lain Akasia, Lamtoro, Kaliandra.

b. Penanaman dan pengembangan pohon kayu diarahkan pada lahan kritis terlantar, bukan lahan pertanian pangan produktif.

c. Mencadangkan lahan marginal tertentu yang dialokasikan khusus untuk tanaman kayu cepat tumbuh penghasil biomassa, misalnya berupa Hutan Tanaman.

d. Pemanfaatan biomassa pertanian untuk penghasil energi tidak mengganggu ketahanan pangan nasional, diutamakan menggunakan residu atau limbah dari produksi pertanian dan kehutanan;

e. Mendorong perkembangan industri pengolahan dan proses produksi pellet biomassa melalui kerjasama saling menguntungkan dengan petani/masyarakat budidaya hutan.

\subsubsection{Perluasan Pemanfaatan dan Permintaan Energi Biomassa di Dalam Negeri:}

a. Mendorong pengembangan pemanfaatan teknologi tungku biomassa yang efisien dalam pembakaran dan sehat untuk meningkatkan peningkatan keamanan dan efisiensi pemanfaatan biomassa untuk sektor rumah tangga dan Usaha Kecil Menengah (UKM), khususnya pedesaan dan sub urban area.

b. Memberikan subsidi bagi EBT biomassa dan pengenaan pajak pada industri yang mengemisi karbon untuk mendorong penggunaan bahan bakar kayu/pelet kayu untuk pembakaran boiler menggantikan batu bara.

c. Mendorong pemanfaatan limbah biomassa yang dihasilkan sebagai sumber energi bagi industri agribisnis.

d. Pembangunan pembangkit listrik biomassa off grid untuk meningkatkan rasio elektrifikasi pulau kecil dan terpencil.

e. Mendorong penggunaan biomassa untuk substitusi penggunaan batubara pada pembangkit listrik PLTU.

\subsubsection{Pengembangan sistem kelembagaan tata kelola industri dan pasar pelet kayu:}

a. Mewajibkan produsen energi biomassa untuk mengisi pasar domestik (Domestic Market Obligation), meskipun tetap diperbolehkan ekspor.

b. Menyusun peta jalan pengembangan industri biomassa dengan melibatkan pemangku kepentingan terkait.

c. Mempromosikan keterlibatan masyarakat dalam industri bioenergi. 


\section{Daftar Pustaka}

Evans, Piers. 2013. Wood-based Biomass Blossoming in Asia. Renewable Energy World magazine. (http://www.renewableenergyworld.com/rea/news/article/)

Hoefnagels, R. ,T. Cornelissen, M. Junginger, and A. Faaij. 2013. Capacity Study for Solid Biomass Facilities. Port of Rotterdam Authority and Copernicus Institute of Sustainable Development Utrecht University.

Cocchi, Maurizio. 2011. Global Wood Pellet Industry Market and Trade Study. IEA Bioenergy.

Junginger, M. 2011. World Biomass Supply and Demand. AEBIOM Bioenergy Conference 2011. June 29-30, 2011, Brussels - Belgium.

Kersh, K. and A. Soare. 2013. Finding Feedstocks for the Bio-Based Fuels and Chemicals of Today and 2030. Lux Research Report.

PennEnergy. 2013. Report: Asia to take lead in biomass power production. (http://www. pennenergy.com/articles/pennenergy/2013/11/report-asia-to-take-lead-in-biomasspower-production.html)

Prastowo, B. 2013. Biobased-Economy: Biomasa Pertanian dan Teknologi Biofuel Generasi Dua Serta Relevansi Riset Pertanian Ke Depan (Agriculture Biomass, Second Generation Biofuel Technology and the Relevance of Future Agriculture Research). Presentation at Badan Litbang Pertanian, Medan.

Prastowo, B. 2012. Biomass Availability and Identification of Feedstock Potential. International Workshop on Bio-energy, CCS and BECCS: Options for Indonesia. Jakarta 2122 September 2012. UKP4 Republic of Indonesia.

Singh, R. and A. D. Setiawan. 2013. Biomass energy policies and strategies: Harvesting potential in India and Indonesia. Renewable and Sustainable Energy Reviews 22:332-345.

Stelte, Wolfgang. 2012. Global Market for Wood Pellets and Price Development. Danish Technological Institute.

ZREU (Zentrum fur rationell Energieanwendung und Umwelt $\mathrm{GmbH}$ ), 2000. Biomass in Indonesia-Business Guide. German Energy Saving Project.

Thacker, Harsh. 2013. Strong Regulatory Push Can Jumpstart The Dormant Biomass Sector In Indonesia. Frost and Sullivan. 25 March 2013 (http://www.frost.com/sublib/ displaymarket-insight.do?id=275795017)

Dewan Energi Nasional. 2015. Ketahanan Energi Indonesia 2015. Sekretariat Jenderal Dewan Energi Nasional. Jakarta. 